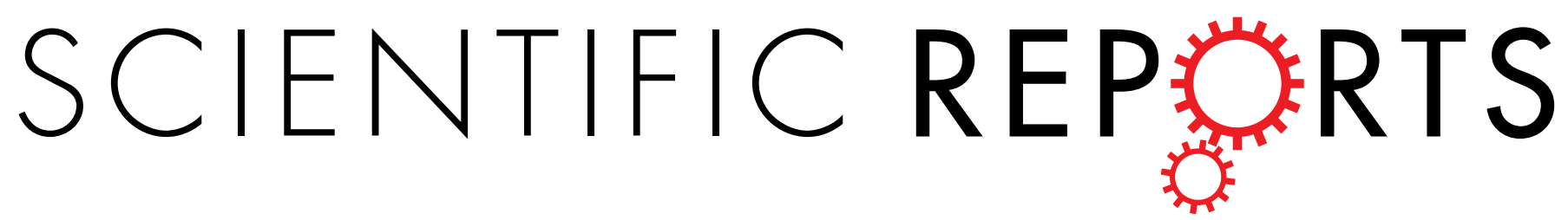

Received: 29 December 2017

Accepted: 14 June 2018

Published online: 29 June 2018

\title{
Potential Application of
}

Saccharomyces cerevisiae and Rhizobium Immobilized in Multi Walled Carbon Nanotubes to Adsorb Hexavalent Chromium

\author{
T. Sathvika ${ }^{1}$, Amitesh Soni ${ }^{1}$, Kriti Sharma ${ }^{1}$, Malipeddi Praneeth ${ }^{1}$, Manasi Mudaliyar ${ }^{2}$, \\ Vidya Rajesh ${ }^{2} \&$ N. Rajesh ${ }^{1}$
}

The presence of harmful contaminants in the waste stream is an important concern worldwide. The convergence of biotechnology and nanoscience offers a sustainable alternative in treating contaminated waters. Hexavalent chromium, being carcinogenic deserves effective and sustainable methods for sequestration. Here in, we report the immobilization of a prokaryote (Rhizobium) and eukaryote (Saccharomyces cerevisiae) in multiwalled carbon nanotubes (MWCNTs) for the effective adsorption of hexavalent chromium. The carboxylic groups were introduced into the MWCNTs during oxidation using potassium permanganate and were subjected to EDC-HOBT coupling to bind with microbial cell surface. FTIR, TGA, BET, FESEM-EDAX, HRTEM, XPS and confocal microscopy were the investigative techniques used to characterize the developed biosorbents. Experimental variables such as $\mathrm{pH}$, adsorbent dosage, kinetics, isotherms and thermodynamics were investigated and it was observed that the system follows pseudo second order kinetics with a best fit for Langmuir isotherm. Electrostatic interactions between the functional groups in the microbial cell wall and hydrochromate anion at $\mathrm{pH} 2.0$ propel the adsorption mechanism. The lab scale column studies were performed with higher volumes of the $\mathrm{Cr}(\mathrm{VI})$ contaminated water. Sodium hydroxide was used as the desorbing agent for reuse of the biosorbents. The sustainable biosorbents show prospects to treat chromium contaminated water.

Heavy metal contamination of water bodies leads to metal bioaccumulation in various forms, posing serious threat to the ecosystem. Heavy metals $(\mathrm{Pb}, \mathrm{Cr}, \mathrm{As}, \mathrm{Hg}, \mathrm{Cd})$ are released into the water by various industrial activities thereby accumulating in food chain due to the binding ability with proteins causing deleterious effects in living beings ${ }^{1}$. Chromium is one of the widely used strategic metal in several industrial applications such as electroplating, leather tanning, and cement and catalyst production ${ }^{2}$. Chromium alloy coatings (CrAlSiN) are used in high speed machining applications since it enhances the metal resistant properties by encountering oxidation and corrosion ${ }^{3}$. Chromium exists in several oxidation states of which +3 and +6 are stable. Minimal amount of $\mathrm{Cr}(\mathrm{III})$ is required for glucose metabolism in the body whereas most of the $\mathrm{Cr}(\mathrm{VI})$ is a man-made carcinogen wherein its contamination is in limelight because of its cytotoxicity and genotoxicity ${ }^{2,4}$. Within the living cell, $\mathrm{Cr}(\mathrm{VI})$ undergoes reduction by producing various reaction intermediates such as $\mathrm{Cr}(\mathrm{V}), \mathrm{Cr}(\mathrm{IV})$, reactive oxygen species (ROS), peroxides, radicals and finally to $\mathrm{Cr}$ (III) which causes oxidative damage to DNA and affects DNA replication ${ }^{5}$. The USEPA ${ }^{6}$ has imposed stringent rules on the safe limit of total $\mathrm{Cr}$ in drinking water as $0.1 \mathrm{mg} \mathrm{L}^{-1}$. Several conventional methods such as precipitation, coagulation, ion exchange, adsorption, membrane filtration are used for treating metal contaminated water among which adsorption is the most effective and economical

${ }^{1}$ Department of Chemistry, Birla Institute of Technology and Science, Pilani, Hyderabad campus, Jawahar Nagar, Hyderabad, 500 078, India. 'Department of Biological Sciences, Birla Institute of Technology and Science, Pilani, Hyderabad campus, Jawahar Nagar, Hyderabad, 500 078, India. Correspondence and requests for materials should be addressed to N.R. (email: nrajesh05@gmail.com) 
approach $^{7}$. Therefore development of efficient adsorbents is necessary to remediate $\mathrm{Cr}(\mathrm{VI})$ being also important studying their reusability.

Chemical adsorbents developed to remediate $\mathrm{Cr}(\mathrm{VI})$ quite recently are xanthum gum grafted polyaniline zinc oxide nanocomposite ${ }^{8}$, branched polyethylenimine grafted electrospunpolyacrylonitrile ${ }^{9}$, polyaniline coated titanate nanobelt ${ }^{10}, \mathrm{MoS}_{2} /$ reduced graphene oxide ${ }^{11}$ and $\mathrm{Fe}_{2} \mathrm{O}_{3}$ /graphitic $\mathrm{C}_{3} \mathrm{~N}_{4}$ graphene nano composite ${ }^{12}$. Though the chemical based adsorbents show high adsorption capacity for removing heavy metals, their disposal is a major concern. Low cost and naturally available adsorbents such as biopolymers, agricultural wastes, microbes (bacteria/yeast/fungi) are used to remediate heavy metals as they are abundantly availa$\mathrm{ble}^{13}$. The chitosan/graphene-oxide/montmorillonite composite for $\mathrm{Cr}(\mathrm{VI})$ adsorption developed by Yu et al. ${ }^{14}$ showed a very good adsorption capacity of $87.03 \mathrm{mg} \mathrm{g}^{-1}$. An agricultural corn bract waste was functionalised with polyethylenimine showed excellent performance for the removal and recovery of $\mathrm{Cr}(\mathrm{VI})$ from aqueous solutions ${ }^{15}$. Pseudochrobactrum asaccharolyticum isolated from $\mathrm{Cr}(\mathrm{VI})$ contaminated soils could completely remove $100 \mathrm{mg} \mathrm{L}^{-1}$ of hexavalent chromium in 144 hours $^{16}$.

Microbes play a vital role in bioremediation of heavy metals by involving two mechanisms. A passive biosorption process takes place in living/non-living/dead microbes which is independent of microbe metabolism, and an active uptake which is a metabolism dependent process and occurs only in living microbes. Bioaccmulation is the process linking both active and passive modes of metal uptake $e^{5,17}$. The direct use of microbes in its native form for metal removal has several disadvantages such as poor mechanical strength, difficulty in microbe separation from the solution and there is always a possibility of loss of microbial mass after regeneration studies. To combat the disadvantages, microbes are immobilized in suitable matrices which help to improve the cell strength, rigidity, porosity and metal removal ability ${ }^{18}$. Aspergillus BRVR immobilized in montmorillonite and cellulose enhanced the $\mathrm{Cr}(\mathrm{VI})$ metal uptake capacity of microbes ${ }^{19,20}$, the exopolymeric substances (EPS) of Pseudomonas strains reduced majority of $\mathrm{Cr}(\mathrm{VI})$ to $\mathrm{Cr}(\mathrm{III})$ involving adsorption coupled reduction mechanism ${ }^{21}$, in an anaerobic sludge, $\mathrm{Cr}(\mathrm{VI})$ is reduced to $\mathrm{Cr}(\mathrm{III})$ by sulfidogenesis and also direct reduction of $\mathrm{Cr}(\mathrm{VI})$ was observed by chromate utilizing bacteria such as Microbacterium ${ }^{22}$. Therefore the possibility of utilizing microbes remain promising making the microbe immobilized matrices open for exploration as suitable biosorbents.

An eukaryotic unicellular microbe Saccharomyces cerevisiae (S.cerevisiae) commonly known as baker's yeast is easily available and is known to have broad applications in food industry ${ }^{23}$ such as wine making, brewing, baking etc., As S. cerevisiae is classified under Generally Recognised as Safe (GRAS) product, it is widely used in industrial water treatment ${ }^{24}$. Sathvika et al ${ }^{25}$ developed microbe based biosorbents with yeast immobilized in glutaraldehyde crosslinked cellulose matrix for the effective removal of $\mathrm{Cr}(\mathrm{VI})$ with a monolayer adsorption capacity of $23.61 \mathrm{mgg}^{-1}$. Titania-yeast nanocomposite showed excellent potential of $99.2 \%$ removal for hexavalent chromium ${ }^{23}$.

A prokaryotic nitrogen fixing bacteria Rhizobium is a symbiotic, rod shaped, gram negative bacteria which is a potential biofertilizer for plants. It also helps in biological nitrogen fixation thereby influencing the agricultural productivity and is used in controlling root rot infections caused by fungi ${ }^{26,27}$. The legumes inoculated with Rhizobium inoculants is a common agriculture practice, which is a cost effective process to provide nutrients to the bacteria. Sludge generated from the agro based industries is rich in carbon and nitrogen sources which helps in the growth of Rhizobium thereby offering a green alternative to treat waste water as well as reducing the cost of inoculant preparation ${ }^{28}$. The activated biomass of Rhizobium leguminosarum could remove upto $77.3 \pm 4.3 \%$ $\mathrm{Cr}(\mathrm{III})$ at $35^{\circ} \mathrm{C}$ at $\mathrm{pH} 7.0^{29}$. An ND2 Rhizobium isolate from the root nodules of Phaseolus vulgaris turned out to be a potential biosorbent for $\mathrm{Cr}(\mathrm{VI})$ removal as well as promoting the growth properties of plant thereby increasing the agricultural productivity ${ }^{30}$. Understanding the potential of these two varied microbes is an interesting add-on for comparative analysis.

Nano- sized materials with their outstanding properties have attracted the attention of scientists and could efficiently be utilized for varied applications. The $\mathrm{sp}^{2}$ hybridized carbon nanotubes (CNT) is one of the interesting forms of elemental carbon categorized into two varieties. The first type is multiwalled carbon nanotubes (MWCNTs) which has concentric rings with a definite spacing between the layers and the second form is single walled carbon nanotubes (SWCNTs) which has a single layer cylinder. Significant progress has been made in the utilization of CNTs for the efficient removal of metal ions and pollutants as they possess large surface area, high mechanical strength, and excellent thermal, electrical properties and are small, hollow and layered structures ${ }^{31}$. Several MWCNTs adsorbents were developed for the treatment of aqueous solutions contaminated with $\mathrm{Cr}(\mathrm{VI})$. Lu et al..$^{32}$ developed magnetic $\mathrm{Fe}_{2} \mathrm{O}_{3}$ nanoparticle-MWCNTs composite and was checked for the efficient removal of $\mathrm{Cr}(\mathrm{VI})$ at different temperatures with a $\mathrm{q}_{\max }$ of $42.02 \mathrm{mg} \mathrm{g}^{-1}$ at $35^{\circ} \mathrm{C}$. Fe- $\mathrm{Ag} / \mathrm{f}-\mathrm{MWCNT} / \mathrm{PES}$ Nanostructured-Hybrid Membranes developed by Masheane et al. could remove $94.8 \%$ of $\mathrm{Cr}(\mathrm{VI})$ from aqueous solution $^{33}$. Chitosan was immobilized in nanoparticles and carbon nanotubes by forming a nanocomposite which could efficiently remove $\mathrm{Cr}(\mathrm{VI})$ up to $84 \%$ within a short contact time ${ }^{34}$. Reports involving microbe-MWCNTs combination for the sequestration of heavy metals are scarce. Yan et al. ${ }^{35}$ reported MWCNTs -calcium alginate complex immobilized in Shewanella oneidensis which showed higher reduction capacity of $\mathrm{Cr}(\mathrm{VI})$. Pseudomonas aeruginosa was immobilized in CNTs for effective adsorption of various heavy metals with $\mathrm{q}_{\max } 6.60 \mathrm{mg} \mathrm{g}^{-1}$ for cobalt, $6.18 \mathrm{mg} \mathrm{g}^{-1}$ for cadmium, $6.07 \mathrm{mg} \mathrm{g}^{-1}$ for lead, $5.83 \mathrm{mg} \mathrm{g}^{-1}$ for manganese, $6.23 \mathrm{mg} \mathrm{g}^{-1}$ for chromium (III) and $5.25 \mathrm{mgg}^{-1}$ for $\mathrm{Ni}^{36}$. Following a thorough literature review, we found there are no comparative studies on bacteria-MWCNTs and yeast-MWCNTs combination for sequestration of $\mathrm{Cr}(\mathrm{VI})$. In the current study, we demonstrate the differences in the efficiency of $\mathrm{Cr}(\mathrm{VI})$ uptake by an eukaryote (yeast) and a prokaryote (Rhizobium) immobilized in multiwalled carbon nanotubes. The pristine MWCNTs were oxidised and then were involved in coupling reaction with the amines present on the cell wall of microbes to form amide which react with hydrochromate ion and thus sequesters $\mathrm{Cr}$ (VI) from aqueous solutions. This would also pave way to explore the mechanistic and physiological variations leading to the differences in metal adsorption efficiencies. 

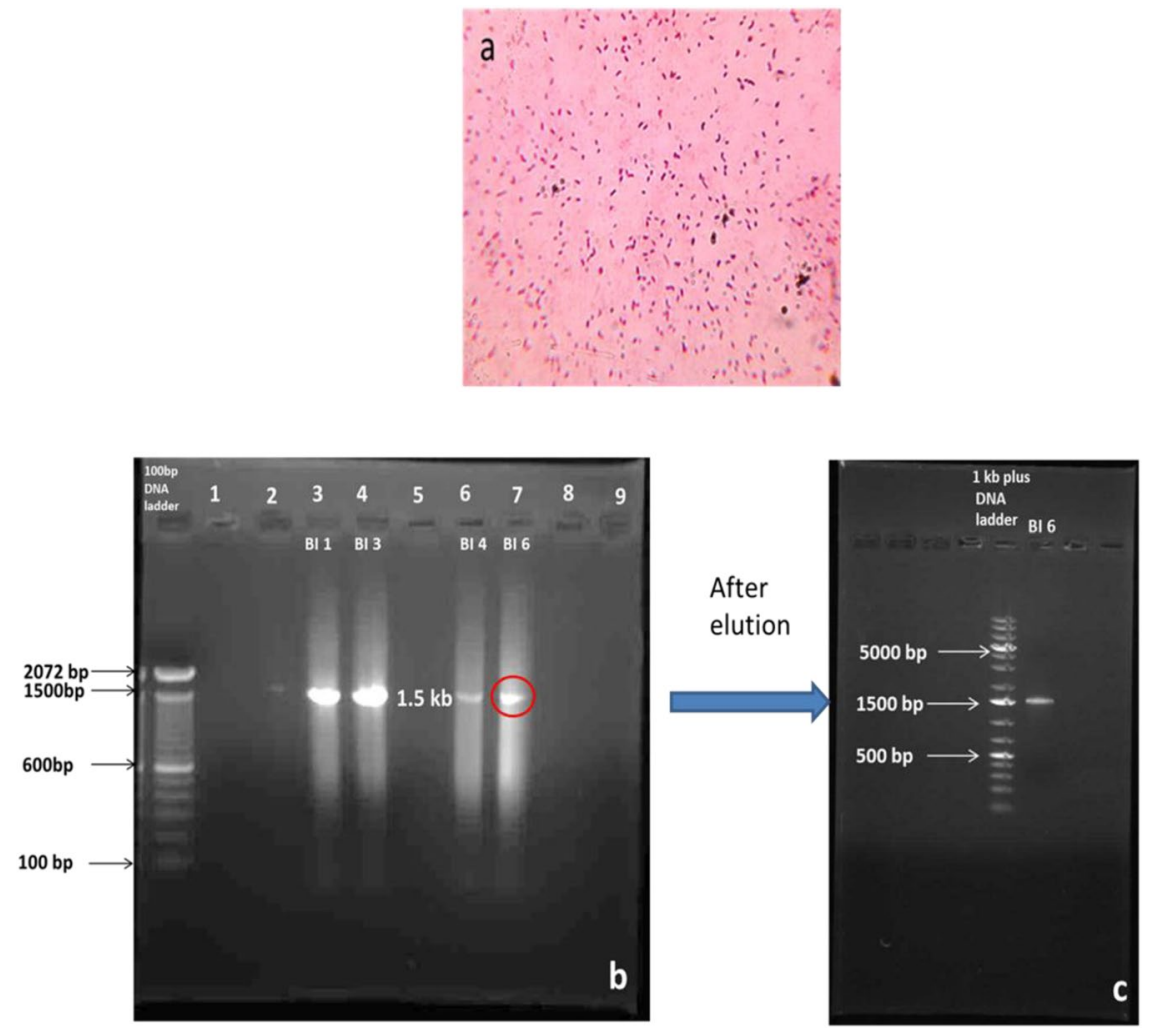

Figure 1. (a) Gram stain image of Rhizobium BVR (b) Gel picture of amplified products of 16S rDNA (1.5 kb) of the bacterial isolates; lane 1-100 bp DNA ladder Invitrogen (cat no: 15628050)]; 3 - bacterial isolate BI 1,; 4bacterial isolate BI 3; 6 - bacterial isolate BI 4; 7- bacterial isolate BI 6. (c) Gel elution image of BI 6 [1 kb DNA ladder, Thermo scientific (cat no: SM1331)].

\begin{tabular}{|l|l|l|l|l|l|l|l|l|}
\hline Strain & Shape & Motility & Gram test & Indole & $\begin{array}{l}\text { Methyl } \\
\text { red }\end{array}$ & $\begin{array}{l}\text { Voges- } \\
\text { Prokasver }\end{array}$ & Citrate & Starch \\
\hline BI1 & Cocco bacillus & Motile & Gram negative & + & - & - & - & + \\
\hline BI3 & Cocco bacillus & Motile & Gram negative & + & - & - & - & + \\
\hline BI4 & Rods & Motile & Gram negative & - & - & - & + & - \\
\hline BI6 & Rods & Motile & Gram negative & - & - & - & + & - \\
\hline
\end{tabular}

Table 1. Morphological and biochemical characteristics of the bacterial isolates.

\section{Results}

Molecular identification of the isolated microbial strains. The morphological study of the gram stained bacteria (BI 1, 3, 4,6) showed the presence of rod shaped (BI 4,6) and cocco bacilli (BI 1,3) gram negative bacteria (Fig. 1a). The isolated bacteria formed circular, translucent, white mucoid colonies on YMA Congo red medium which is a positive test for Rhizobium. Further biochemical tests were performed and the results of four isolates were tabulated in Table 1. 16S rDNA sequencing was performed to confirm the genus of the bacterial isolates with $1500 \mathrm{bp}$ amplicon obtained after PCR (Fig. 1b,c). Among the sequences obtained, the database available in NCBI gene bank BI 6 strain showed 99\% similarity to Rhizobium species (Fig. 2a) and thus bacterial isolate was named as Rhizobium BVR which was used for further study. The sequence was assigned an accession number MF136764 when submitted to NCBI Genbank. The evolutionary relationships as seen in the phylogenetic tree (Fig. 3) generated using MEGA 6.0 version showed the Rhizobium BVR is distantly related to other Rhizobium species. The MALDI TOF spectrum also confirmed the isolated strain to be Rhizobium (Fig. 2b). The confirmation of S.cerevisiae through the morphological and biochemical tests was reported in our previous studies ${ }^{25}$.

Characterisation of the biosorbent. The FTIR spectra of pristine and oxidised CNTs, biosorbents CNTR (multiwalled carbon nanotubes-Rhizobium) and CNTY (multiwalled carbon nanotubes-yeast) before and after $\mathrm{Cr}(\mathrm{VI})$ adsorption were recorded (Fig. 4). The pristine MWCNTs was oxidised using $\mathrm{KMnO}_{4}$ and $\mathrm{H}_{2} \mathrm{SO}_{4}$. The peak at $1732 \mathrm{~cm}^{-1}$ corresponds to $\mathrm{C}=\mathrm{O}$ of carboxylic acid confirming the introduction of $\mathrm{COOH}$ groups on the surface of MWCNTs. The carboxyl groups fluctuations leads to comparatively broader $\mathrm{O}-\mathrm{H}$ stretch than in pristine CNTs. Symmetric and asymmetric $\mathrm{COO}^{-}$stretchings ${ }^{37}$ gives rise to two peaks at $1387 \mathrm{~cm}^{-1}$ and $1625 \mathrm{~cm}^{-1}$. The successful immobilization of microbe in MWCNTs is assisted by EDC-HOBT coupling by forming amide 
$\underline{\mathbf{a}}$

\begin{tabular}{|c|c|c|c|c|c|c|c|}
\hline & Description & $\begin{array}{l}\text { Max } \\
\text { score }\end{array}$ & $\begin{array}{l}\text { Total } \\
\text { score }\end{array}$ & $\begin{array}{l}\text { Query } \\
\text { cover }\end{array}$ & \begin{tabular}{|c|}
$E$ \\
value
\end{tabular} & Ident & Accession \\
\hline$\square$ & Rhizobium aequptiacum strain $101016 \mathrm{~S}$ ribosomal RNA partial sequence & 2425 & 2425 & $98 \%$ & 0.0 & $99 \%$ & $\underline{N R} 137399.1$ \\
\hline$\square$ & Rhizobium binae strain BLR195 16 S ribosomal RNA, partial sequence & 2425 & 2425 & $98 \%$ & 0.0 & $99 \%$ & $\underline{\text { NR } 137242.1}$ \\
\hline$\square$ & Rhizobium banqladeshense strain BLR175 $16 \mathrm{~S}$ ribosomal RNA partial sequence & 2425 & 2425 & $98 \%$ & 0.0 & $99 \%$ & $\underline{\text { NR } 137241.1}$ \\
\hline$\square$ & Rhizobium banaladeshense strain $1017 \pi$ 16S ribosomal RNA gene, partial sequence & 2425 & 2425 & $98 \%$ & 0.0 & $99 \%$ & $\underline{\mathrm{J} Q 670241.3}$ \\
\hline$\square$ & Rhizobium banqladeshense strain BLR175 16 S ribosomal RNA qene, partial sequence & 2425 & 2425 & $98 \%$ & 0.0 & $99 \%$ & $\underline{\mathrm{JN} 648931.2}$ \\
\hline$\square$ & Rhizobium etli strain CCBAU 6583016 S ribosomal RNA gene, partial sequence & 2425 & 2425 & $98 \%$ & 0.0 & $99 \%$ & EU618034.1 \\
\hline$\square$ & Rhizobium etli strain CCBAU 6570816 S ribosomal RNA gene, partial sequence & 2425 & 2425 & $98 \%$ & 0.0 & $99 \%$ & EU618033.1 \\
\hline & Rhizobium sp. Dz12 16 S ribosomal RNA gene, partial sequence & 2425 & 2425 & $98 \%$ & 0.0 & $99 \%$ & AY210710.1 \\
\hline
\end{tabular}

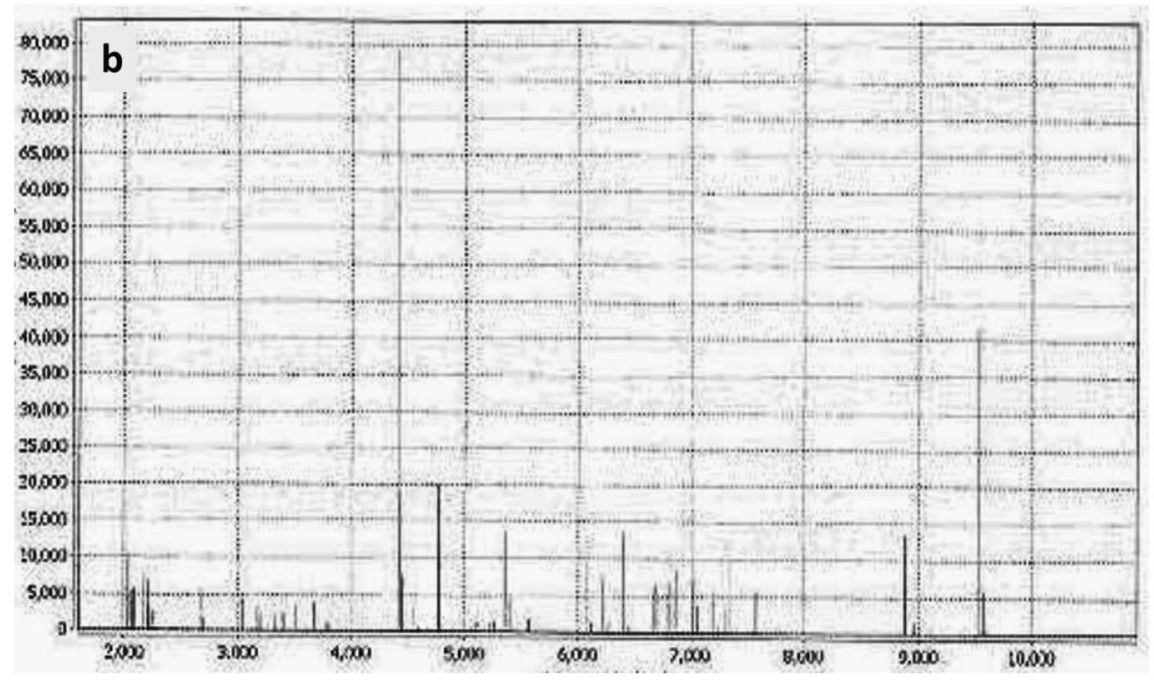

Figure 2. (a) Blast search for BI 6 sequence confirming Rhizobium species (b) MALDI TOF of Rhizobium BVR.

bond around $1644-1648 \mathrm{~cm}^{-1}$ and also this peak is due to amide- 1 of protein-peptide bond from the microbes ${ }^{38}$. The disappearance of carboxyl $\mathrm{C}=\mathrm{O}$ peak after the amide formation indicates the involvement of carboxyl groups present on the surface of MWCNTs in amide formation. The band in the range $1541-1546 \mathrm{~cm}^{-1}$ corresponds to amide-II of in plane $\mathrm{N}-\mathrm{H}$ bending ${ }^{39}$. After $\mathrm{Cr}(\mathrm{VI})$ adsorption the changes in the amide bond, $\mathrm{O}-\mathrm{H}$ and $\mathrm{C}=\mathrm{O}$ wavenumbers indicate they were involved in $\mathrm{Cr}(\mathrm{VI})$ uptake by protonating in acidic medium thereby forming electrostatic interactions with $\mathrm{Cr}(\mathrm{VI})$. The field emission scanning electron microscope (FESEM) and high resolution scanning electron microscopy (HRTEM) images of pristine, oxidised MWCNT and the biosorbent before and after $\mathrm{Cr}(\mathrm{VI})$ adsorption were recorded. The tiny lumps in FESEM images (Fig. S1c,d) and the particulates on MWCNTs in HRTEM images (Fig. S2c) indicate microbial immobilizations. The oxidation process caused minimal irregularities in the wall surfaces of $\mathrm{MWCNTs}^{37}$ as indicated in Fig. S2. The elemental analysis of the biosorbent before and after adsorption of $\mathrm{Cr}(\mathrm{VI})$ was recorded using Energy Dispersive X-ray Spectroscopy indicating $\mathrm{Cr}(\mathrm{VI})$ adsorption onto the biosorbent with characteristic peak between 5-6 keV (Fig. S1i-iv).

The presence of $\mathrm{Cr}(\mathrm{VI})$ on the biosorbent surface was also strongly supported by the X-ray photo electron spectroscopy (XPS). The base peak was corrected to $284.8 \mathrm{eV}$ in the high resolution carbon scan. The survey scan of the biosorbents confirmed the presence of $\mathrm{C}, \mathrm{N}, \mathrm{O}$ and $\mathrm{Cr}$ respectively. The high resolution spectra of $\mathrm{Cr} 2 \mathrm{p}$ gave two peaks Cr2 $\mathrm{p}_{3 / 2}$ and $\mathrm{Cr} 2 \mathrm{p}_{1 / 2}$. Cr2 $\mathrm{p}_{3 / 2}$ is deconvoluted into two peaks at $577 \mathrm{eV}, 578 \mathrm{eV}$ which represent $\mathrm{Cr}(\mathrm{III})$ and $\mathrm{Cr}(\mathrm{VI})$ respectively ${ }^{40}$ and $\mathrm{Cr} 2 \mathrm{p}_{1 / 2}$ at $587 \mathrm{eV}$ corresponds to $\mathrm{Cr}(\mathrm{VI})$ in both CNTR and CNTY shown in Fig. 5. Instant reduction of $\mathrm{Cr}(\mathrm{VI})$ was not observed after treatment with the biosorbents due to short agitation period and this was confirmed through chromium speciation by ion chromatography. The XPS analysis showed the presence of $\mathrm{Cr}$ (III) and as reported earlier ${ }^{25} \mathrm{Cr}$ (III) formation on the biosorbent surface was evident only after 4-5 days. This could be due to extended interactions of $\mathrm{Cr}(\mathrm{VI})$ with the carbon and specific iron regulated surface proteins in the microbes ${ }^{41,42}$. The Brunauer-Emmett-Teller (BET) adsorption isotherm was used to measure the specific surface area of the biosorbent ${ }^{43}$. The nitrogen adsorption/desorption curves provided by the BET isotherm gave the surface areas for oxidised MWCNTs as $115.72 \mathrm{~m}^{2} \mathrm{~g}^{-1}, 69.81 \mathrm{~m}^{2} \mathrm{~g}^{-1}$ for CNTR and $37.029 \mathrm{~m}^{2} \mathrm{~g}^{-1}$ for CNTY. The average pore volume and pore diameter was found to be as follows: Oxidised CNTs $\left(1.3857 \mathrm{~cm}^{3} \mathrm{~g}^{-1}\right.$, $47.897 \mathrm{~nm})$, CNTR $\left(0.9183 \mathrm{~cm}^{3} \mathrm{~g}^{-1}, 52.613 \mathrm{~nm}\right)$ and CNTY $\left(0.6573 \mathrm{~cm}^{3} \mathrm{~g}^{-1}, 71.0 \mathrm{~nm}\right)$ respectively. These features could be attributed to the difference in the morphological features of the respective microorganisms. The thermal stability of the biosorbents were studied using thermogravimetric analysis (TGA). A sample mass of $2.43 \mathrm{mg}$ of CNTR and $5.569 \mathrm{mg}$ of CNTY were analyzed in air atmosphere at a flow rate of $50 \mathrm{~mL} \mathrm{~min}^{-1}$ in the temperature range $35-800^{\circ} \mathrm{C}$ ramped at $10^{\circ} \mathrm{C}$ per minute. The TGA curves (Fig. 5e) signify that biosorbents were stable at 


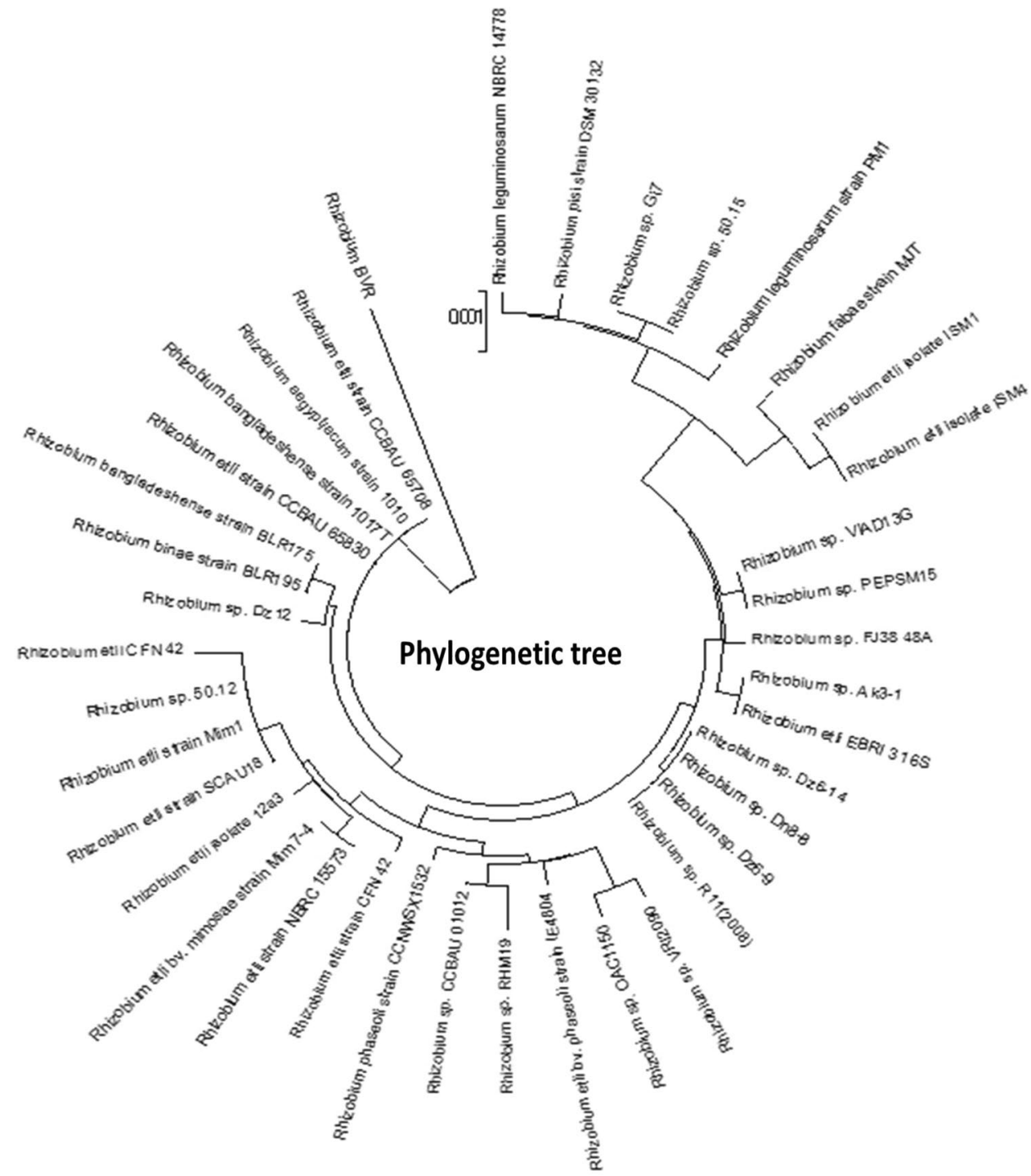

Figure 3. Phylogenetic tree of the Rhizobium BVR created using MEGA (version 6.0).

higher temperatures i.e., till $600^{\circ} \mathrm{C}(\mathrm{CNTY})$ and $677^{\circ} \mathrm{C}(\mathrm{CNTR})$ and the initial loss of mass is due to the moisture present in biosorbents ${ }^{44}$.

The presence of chromium in its +3 and +6 form were also differentiated using laser confocal microscopy using specific rhodamine based chemosensors. The physical properties of RBH such as colorless, non-fluorescent nature owes to its spirolactam structure which is highly stable and detects $\mathrm{Cr}(\mathrm{VI})$ whereas RF is a pale pink solid which exhibits fluorescence and detects $\mathrm{Cr}$ (III). $\mathrm{RBH}$ was dissolved in $10 \mathrm{mmol} \mathrm{L}{ }^{-1} \mathrm{H}_{2} \mathrm{SO}_{4}$ and added to the sample for further detection of $\mathrm{Cr}(\mathrm{VI})$. It was observed that after addition of $\mathrm{RBH}$ to the sample containing $\mathrm{Cr}(\mathrm{VI})$ it turned pink due to the conversion of $\mathrm{RBH}$ to $\mathrm{RB}$ in view of $\mathrm{RBH}$ oxidation caused by $\mathrm{Cr}(\mathrm{VI})$ in acid medium ${ }^{45}$. The excitation and emission was recorded at $560 \mathrm{~nm}$ and $585 \mathrm{~nm}$ respectively. $\mathrm{RF}$ when dissolved in $10 \mathrm{mmol} \mathrm{L}^{-1}$ Tris- $\mathrm{HCl}$ is a colorless solution. The RF was added to the biosorbent with $\mathrm{Cr}(\mathrm{VI})$ which did not show any fluorescence indicating no immediate reduction of $\mathrm{Cr}(\mathrm{VI})$. After 4 days, the addition of biosorbent to RF turned pink due to chelation of RF with $\mathrm{Cr}$ (III) present on the surface of the biosorbent, generating a rhodamine type product in spirolactam by ring opening at $\mathrm{C}-\mathrm{N}$ bond ${ }^{46}$. The excitation and emission for $\mathrm{Cr}$ (III) in $\mathrm{RF}$ was recorded at $525 \mathrm{~nm}$ and $590 \mathrm{~nm}$ respectively. The bright field and fluorescent images of CNTR and CNTY are shown in Figs $3 \mathrm{a}-\mathrm{h}$ and $\mathrm{S} 3 \mathrm{i}$-viii. The images captured before and after addition of RBH confirmed the presence of $\mathrm{Cr}(\mathrm{VI})$ in sample and also $\mathrm{Cr}$ (III) presence was confirmed by the addition of RF which exhibited fluorescence.

Effect of $\mathrm{pH}$, adsorbent dosage and interaction mechanisms. Influence of $\mathrm{pH}$ plays a vital role in the uptake of $\mathrm{Cr}(\mathrm{VI})$ onto the biosorbent. A $0.1 \mathrm{~g}$ weight of each of the biosorbent was weighed in a series of Erlenmeyer flasks and to that $20 \mathrm{~mL}$ of $5 \mathrm{mg} \mathrm{L}^{-1} \mathrm{Cr}$ (VI) solution was added and adjusted to $\mathrm{pH} 2.0-7.0$ and agitated for 3 hours to attain equilibrium. After analysis, it was found that the biosorbents could equally adsorb hexavalent chromium completely at $\mathrm{pH}$ 2.0. At $\mathrm{pH}>2$ it was observed that there was a decrease in the metal uptake (Fig. S4a). This is due to the existence of $\mathrm{Cr}(\mathrm{VI})$ ions in various forms such as hydro chromate $\left(\mathrm{HCrO}_{4}^{-}\right)$ 


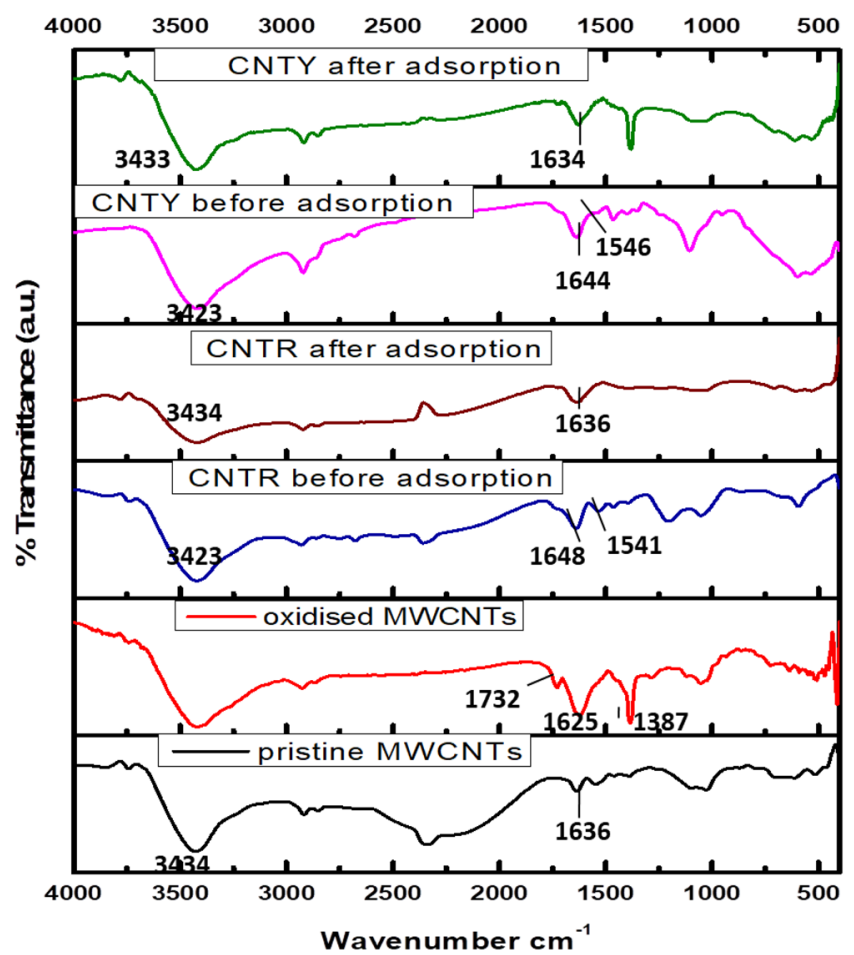

Figure 4. FTIR spectra of pristine, oxidised MWCNTs, before and after Cr(VI) adsorption on CNTR, CNTY.

at $\mathrm{pH} 2-4$, in strongly acidic medium $(\mathrm{pH}<2)$ it exists as dichromate $\left(\mathrm{Cr}_{2} \mathrm{O}_{7}{ }^{2-}\right)$ and at higher $\mathrm{pH}$ as chromate $\left(\mathrm{CrO}_{4}{ }^{2-}\right)$. In acidic medium, the biosorbent surface which has functional groups such as hydroxyl, carboxylic and amide gets protonated and is involved in electrostatic interactions with $\mathrm{HCrO}_{4}{ }^{-}$thus aiding the metal to participate in biosorption (Fig. 6). Amides are usually poor leaving groups hence under highly acidic conditions ( $\mathrm{pH}$ 2.0 ) the carbonyl oxygen of amide is protonated and further the protonation of amide nitrogen is also probable ${ }^{47}$ in influencing the metal uptake. According to HSAB (hard-soft acid base) principle $\mathrm{CrO}_{4}{ }^{2-}<\mathrm{HCrO}_{4}^{-}<\mathrm{OH}^{-}$ with regard to the hardness of the ions ${ }^{25}$. At higher $\mathrm{pH}$, the hydroxide and chromate ions compete each other resulting in the electrostatic repulsion thereby decreasing the $\mathrm{Cr}(\mathrm{VI})$ uptake. The adsorbent dosages were varied from $0.01 \mathrm{~g}$ to $0.5 \mathrm{~g}$ to observe the minimal dosage of the biosorbent which can remediate maximum amount of $\mathrm{Cr}(\mathrm{VI})$ at $\mathrm{pH}$ 2.0. A $20 \mathrm{~mL}$ volume of $5 \mathrm{mg} \mathrm{L}^{-1} \mathrm{Cr}(\mathrm{VI})$ was taken with varying biosorbent dosage and agitated for $180 \mathrm{~min}$ and observed that with $0.1 \mathrm{~g}$, CNTR as well as CNTY could adsorb $\mathrm{Cr}(\mathrm{VI})$ quantitatively indicating the saturation of adsorbent sites (Fig. S4b).

Biosorption kinetics, isotherms and temperature effect studies. The kinetic experiments were performed using $0.1 \mathrm{~g}$ of the biosorbent mixed with $20 \mathrm{~mL}$ of $5 \mathrm{mg} \mathrm{L}^{-1} \mathrm{Cr}(\mathrm{VI})$ at time intervals ranging from 5-180 min. The maximum uptake of the metal ion was observed at $180 \mathrm{~min}$. The data obtained from the plots (Fig. S5a-c) were fitted into the pseudo first order ${ }^{48}$, second order $^{49}$ and intra particle diffusion to evaluate the adsorption kinetics. The kinetic parameters are presented in Table S1. The equations representing pseudo first order and pseudo second order kinetics are given as

$$
\begin{gathered}
\log \left(\mathrm{q}_{\mathrm{e}}-\mathrm{q}_{\mathrm{t}}\right)=\log \mathrm{q}_{\mathrm{e}}-\frac{\mathrm{k}_{1} \mathrm{t}}{2.303} \\
\frac{\mathrm{t}}{\mathrm{q}_{\mathrm{t}}}=\frac{1}{\mathrm{k}_{2} \mathrm{q}_{\mathrm{e}}^{2}}+\frac{\mathrm{t}}{\mathrm{q}_{\mathrm{t}}}
\end{gathered}
$$

The best suited kinetics depends on the experimental data which has the highest regression coefficient and the system follows pseudo second order kinetics with $1.844 \mathrm{mg} \mathrm{g}^{-1}\left(\mathrm{q}_{\text {eexp }}\right), 1.8848 \mathrm{mg} \mathrm{g}^{-1}$ ( $\left.\mathrm{q}_{\text {ecal }}\right)$ for CNTY and $1.8026 \mathrm{mg} \mathrm{g}^{-1}\left(\mathrm{q}_{\text {eexp }}\right), 1.826 \mathrm{mg} \mathrm{g}^{-1}\left(\mathrm{q}_{\text {ecal }}\right)$ for CNTR. The ability of biosorbents to eliminate a unit mass of contaminants under similar conditions is explained by the isotherms. The plot $\mathrm{q}_{\mathrm{t}} \mathrm{vs} \mathrm{t}^{1 / 2}$ relates to the intraparticle diffusion which is evaluated using $q_{t}=k_{i} t^{1 / 2}+C$ where $c$ corresponds to intercept and $k_{i}$ is the intra particle diffusion constant which is obtained from the slope of the plot. The rate at which $\mathrm{Cr}(\mathrm{VI})$ gets adsorbed is mostly influenced by the diffusion mechanisms such as (i) the $\mathrm{Cr}(\mathrm{VI})$ from the bulk of the solution gets transferred onto the CNTR-CNTY biosorbent surface via external mass transfer (ii) intraparticle diffusion ${ }^{50}$ wherein $\mathrm{Cr}$ (VI) diffuses through the pores of the CNTR-CNTY biosorbent. From the plot it was observed that the straight line deviates from the origin having a significant intercept indicating the boundary layer phenomenon also plays role in the adsorption kinetics of hexavalent chromium. 

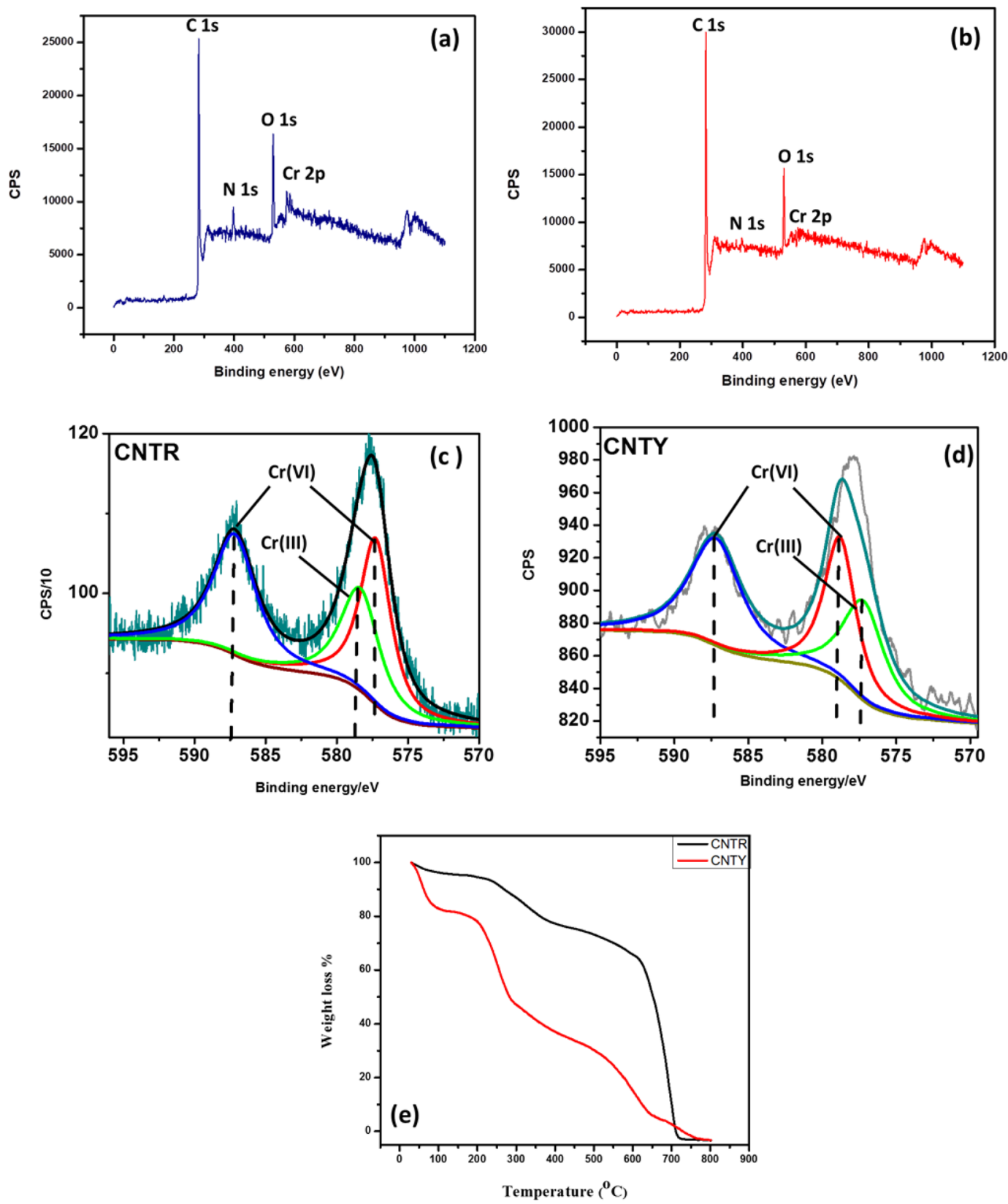

Figure 5. XPS spectra of (a,b) survey scan of CNTR and CNTY (c,d) high resolution chromium scan spectra (e) TGA of the biosorbents.

Among several isotherms, commonly studied theoretical and empirical isotherms are Langmuir and Freundlich ${ }^{51}$. The data obtained from the plots (Fig. S5d,e) and the equations are presented in Table 2. The system assumed a monolayer Langmuir adsorption model as it has the low chi square value and high $\mathrm{R}^{2}$ value. The CNTY biosorbent has an adsorption capacity of $31.605 \mathrm{mg} \mathrm{g}^{-1}$ with an $\mathrm{R}^{2}$ value as 0.96 whereas CNTR has an adsorption capacity of $24.8 \mathrm{mg} \mathrm{g}^{-1}$ with an $\mathrm{R}^{2}$ value of 0.96 . The dimensionless constant $\mathrm{R}_{\mathrm{L}}$ value lies below unity indicating the reversibility of the isotherm which is represented as

$$
\mathrm{R}_{\mathrm{L}}=1 / 1+\mathrm{bC}_{\mathrm{o}}
$$

where $b$ is the Langmuir constant associated to adsorption energy, $C_{o}$ represents the equilibrium concentration of the heavy metal ion. The Freundlich constants $\mathrm{n}$ and $\mathrm{K}_{\mathrm{F}}$ are related to adsorption intensity and its capacity respectively. The values of $\mathrm{n}$ of both the biosorbents are greater than $1(2.17,2.29)$ indicating the favorability of metal adsorption onto the biosorbent. The pristine MWCNTs have an adsorption capacity of $11.93 \mathrm{mg} \mathrm{g}^{-1}$, when oxidised the uptake capacity enhanced to $16.22 \mathrm{mg} \mathrm{g}^{-1}$ and after the addition of Rhizobium and yeast to the MWCNTs adsorption capacity increased to $24.82 \mathrm{mg} \mathrm{g}^{-1}$ and $31.6 \mathrm{mg} \mathrm{g}^{-1}$ respectively.

The thermodynamic parameters such as Gibbs free energy $\left(\Delta \mathrm{G}^{\circ}\right)$, enthalpy $\left(\Delta \mathrm{H}^{\circ}\right)$ and entropy $\left(\Delta \mathrm{S}^{\circ}\right)$ explain the spontaneity of adsorption process. The equilibrium constant $\mathrm{K}$ at different temperatures was derived from 


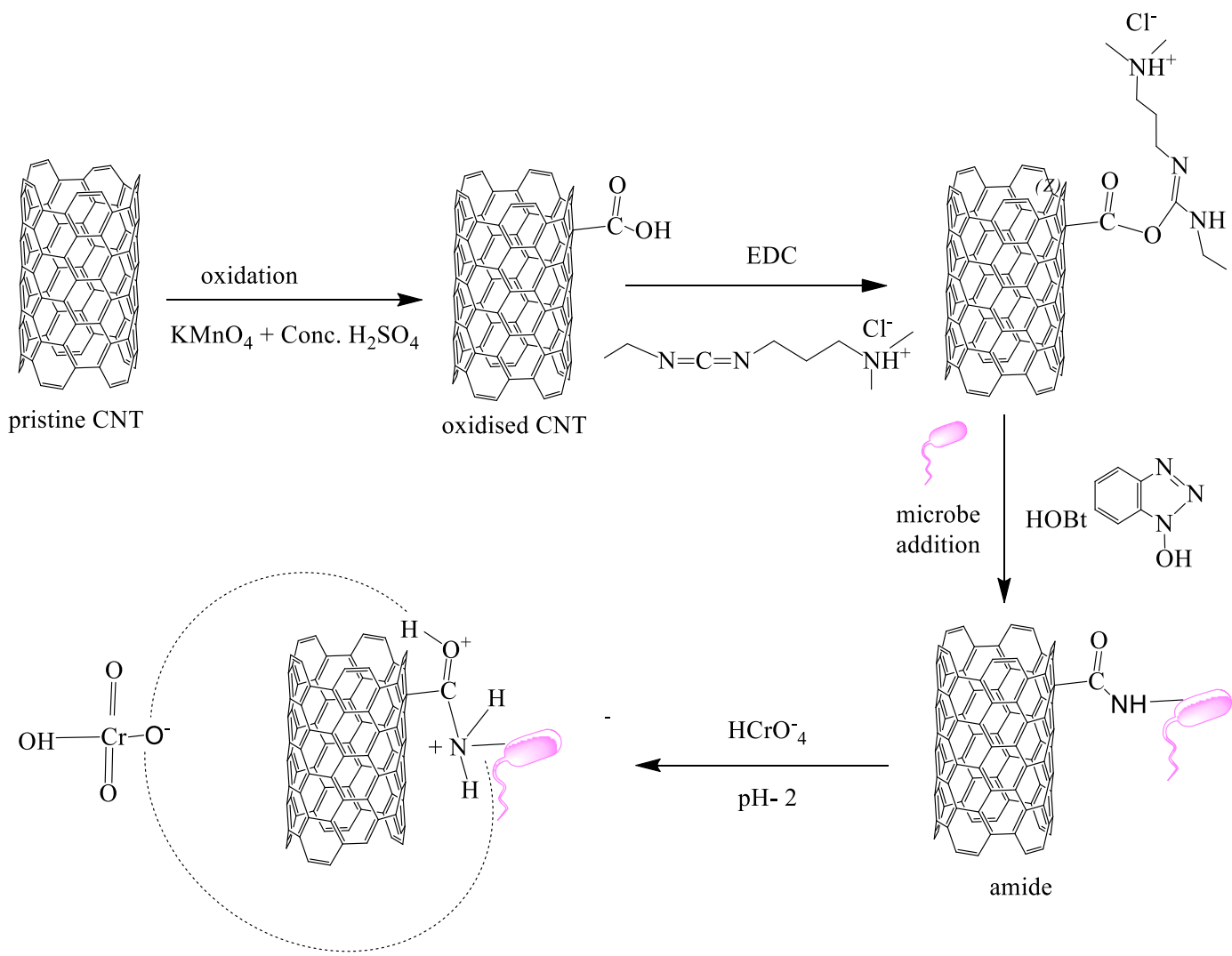

Figure 6. Interaction mechanism of the biosorbents with $\mathrm{Cr}(\mathrm{VI})$.

\begin{tabular}{|c|c|c|c|c|c|}
\hline $\begin{array}{l}\text { Langmuir } \\
\frac{C_{e}}{q_{e}}=\frac{1}{q_{o}^{b}}+\frac{C_{e}}{q_{o}}\end{array}$ & $\mathrm{q}_{\mathrm{o}}\left(\mathrm{mg} \mathrm{g}^{-1}\right)$ & $\mathbf{b}\left(\mathbf{m g}^{-1} \mathbf{L}\right)$ & $\mathbf{R}_{\mathrm{L}}$ & $\mathbf{R}^{2}$ & $\chi^{2}$ \\
\hline CNTY & 31.605 & 0.072 & 0.578 & 0.967 & 1.021 \\
\hline CNTR & 24.82 & 0.043 & 0.695 & 0.962 & 0.46 \\
\hline $\begin{array}{l}\text { Freundlich } \\
\log q_{e}=\log K_{F}-\frac{1}{n} \log C_{e}\end{array}$ & $K_{F}\left(m g^{1-1 / n} g^{-1} L^{1 / n}\right)$ & $\mathbf{n}$ & $\mathbf{R}^{2}$ & $x^{2}$ & \\
\hline CNTY & 3.298 & 2.2925 & 0.854 & 1.667 & \\
\hline CNTR & 2.172 & 2.178 & 0.895 & 0.61 & \\
\hline
\end{tabular}

Table 2. Biosorption isotherm parameters for $\mathrm{Cr}(\mathrm{VI})$ adsorption.

the ratio of $\mathrm{Cr}(\mathrm{VI})$ present on the surface of CNTR, CNTY to that in the liquid phase and fitted into Gibbs free energy equation $(\Delta \mathrm{G}=-\mathrm{RT} \ln \mathrm{K})$. The changes in enthalpy and entropy for the respective biosorbents were obtained from the Van't Hoff plot of ln K against 1/T (Fig. S5f). The negative free energy values indicate the spontaneity in the biosorbent- sorbate interactions and the negative values of enthalpy and activation energy $\left(\mathrm{E}_{\mathrm{a}}=\Delta \mathrm{H}^{\circ}{ }_{\mathrm{ads}}+\mathrm{RT}\right)$ indicates the system involves exothermic adsorption. The negative $\Delta \mathrm{S}^{\circ}$ values indicate the decrease in the disorderliness of the system with increase in temperature ${ }^{25}$. The $\Delta H$ values obtained for CNTR $\left(-31.6 \mathrm{~kJ} \mathrm{~mol}^{-1}\right)$ and CNTY $\left(-72.2 \mathrm{~kJ} \mathrm{~mol}^{-1}\right)$ indicate both the systems involve exothermic physicochemical adsorption ${ }^{19}$. The enthalpy-entropy compensation is well illustrated through the corresponding values obtained for the biosorbents. The adsorption process is more exothermic in CNTY as evident from the largely negative enthalpy values from Table S2. The entropy change is also more negative for CNTY reflecting more orderliness at the biosorbent-solution interphase.

Effect of sample volume, regeneration and interference studies. Laboratory scale column studies were done to test the applicability of developed biosorbents for their sustainability to higher sample volume. A $1.5 \mathrm{~g}$ biosorbent was packed to $2 \mathrm{~cm}$ bed height in a glass column of $30 \mathrm{~cm}$ length with a diameter of $2 \mathrm{~cm}$ and was allowed to settle for a minimum of 2 hours to avoid air voids before the start of the experiment. A Cr(VI) concentration of $5 \mathrm{mg} \mathrm{L}^{-1}$ was prepared and the column was loaded with $50 \mathrm{~mL}$ of $5 \mathrm{mg} \mathrm{L}^{-1}$ at $5 \mathrm{~mL} \mathrm{~min}^{-1}$ flow rate and the eluate concentration was checked periodically for every $10 \mathrm{~mL}$ using ion chromatography. $50 \mathrm{~mL}$ of $5 \mathrm{mg} \mathrm{L}^{-1}$ $\mathrm{Cr}(\mathrm{VI})$ was completely adsorbed effectively. Subsequently, $300 \mathrm{~mL}$ of the $\mathrm{Cr}(\mathrm{VI})$ solution was loaded continuously and the heavy metal was adsorbed completely beyond which there was saturation owing to the non-availability of 
active adsorption sites ${ }^{52}$. A sample volume of $350 \mathrm{~mL}$ and $250 \mathrm{~mL}$ was adsorbed effectively onto CNTY and CNTR respectively as shown in Fig. S6a.

A significant property of the adsorbent is the ability to reuse thereby reducing the operational cost in treating pollutants. Varying sodium hydroxide concentrations $\left(0.1-2.0 \mathrm{~mol} \mathrm{~L}^{-1}\right)$ were tried (Fig. S6b,c) of which $1.0 \mathrm{~mol} \mathrm{~L}^{-1}$ sodium hydroxide was effective in desorbing $\mathrm{Cr}(\mathrm{VI})$ as sodium chromate ${ }^{25}$. It was observed that in CNTY, second, third, fourth, fifth cycles completed $100 \%$ adsorption- desorption cycles beyond which there was a decrease in the adsorption percentage. $70 \%$ adsorption was observed in $6^{\text {th }}$ cycle, $45 \%$ in $7^{\text {th }}$ cycle as shown in Fig. S6d,e. In CNTR, there were four complete adsorption-desorption cycles and the decrease in adsorption was observed from $5^{\text {th }}$ cycle.

A $100 \mathrm{mg} \mathrm{L}^{-1}$ concentration each of various cations such as $\mathrm{Mn}^{+2}, \mathrm{Cu}^{+2} \mathrm{Fe}^{+2}, \mathrm{Co}^{+2}, \mathrm{Ni}^{+2}, \mathrm{~Pb}^{+2}$ and anions such as nitrate, chloride, sulfate were added to $5 \mathrm{mg} \mathrm{L}^{-1} \mathrm{Cr}(\mathrm{VI})$ solution and the adsorption studies were carried out to observe the influence of these ions in the uptake of chromium. It was observed that the adsorption percentage decreased by $2.0 \pm 0.5 \%$ in CNTY as well as CNTR attributed to the interference of anions which compete with hydrochromate ions to occupy the adsorption sites, whereas cations such as $\mathrm{Fe}$ (II) and Mn (II) have the ability to reduce $\mathrm{Cr}(\mathrm{VI})$ to $\mathrm{Cr}(\mathrm{III})^{53}$.

\section{Discussion}

The oxidised MWCNTs have larger surface area compared to the microbe immobilized carbon nanotubes. Also the pore parameters such as pore volume and pore diameter contribute to the surface area. In the current method the oxidised MWCNTs have a higher pore volume compared to microbe immobilized MWCNT. However for adsorption studies apart from the surface area, availability of more functional groups also aid in enhancing the metal uptake. The surface of the microbial cell wall have carboxyl, hydroxyl and amine functionalities which tend to participate in the metal uptake along with functionalised MWCNTs thereby increasing the $\mathrm{Cr}(\mathrm{VI})$ adsorption capacity.

Clearly yeast showed better adsorption capacity and the difference can be attributed to the morphological properties such as cell wall composition. The Rhizobium cell wall composition is similar to gram negative bacterial cell wall. Major component of cell wall is peptidoglycan which is made up of alanine, amino sugars, glutamic acid and diaminopimelic acid. It also contains lipo-polysaccharide which is composed of uronic acid, glucosamines, glucose, 2-keto, 3-deoxy octanoic acid, mannose and galactose which have functional groups such as amines, carboxyl, hydroxyl and phosphates ${ }^{54}$. The yeast cell wall composition is similar to gram positive bacteria which is majorly made up of polysaccharides such as $\beta$-glucans $(60 \%)$, mannoproteins (40\%), and chitin $(2 \%)^{55}$ which mainly consists of amines, carboxylic and hydroxyl groups in larger amounts than in Rhizobium cell wall. Although, both the microbial cell walls are made up of polysaccharides, lipids and proteins, yeast cell wall has (1-10\%) more lipid content ${ }^{56}$ owing to the presence of more functional groups. Hence, in the current work the uptake of chromium (VI) in yeast is higher as compared to Rhizobium.

When microbes are added as amine sources to the EDC-HOBT coupling reactions with oxidised MWCNTs, a covalent interaction in the form of amide bond is formed between them which participates in $\mathrm{Cr}(\mathrm{VI})$ adsorption in acidic medium and also the available $\mathrm{OH}, \mathrm{COOH}$ groups in microbes augments the electrostatic interactions with the hydrochromate ion. The comparison of adsorption capacities of various adsorbents with the current developed biosorbents is given in Table S3. Clearly, the microbe immobilized MWCNTs shows a higher adsorption capacity as compared to the pristine and oxidised MWCNTs.

In conclusion, this work has highlighted the confluence of biotechnology and nano materials as an emerging area towards heavy metal remediation. The proposed methodology has illustrated the ability of two diverse microorganisms in oxidised multiwalled carbon nanotubes as effective adsorbents to sequester chromium in the +6 oxidation state. The biosorbents CNTR and CNTY followed Langmuir isotherm with $24.86 \mathrm{mg} \mathrm{g}^{-1}$ and $31.6 \mathrm{mg} \mathrm{g}^{-1}$ adsorption capacities respectively. The biosorption process was exothermic, spontaneous and pseudo second order model was effective in understanding the adsorption kinetics. The mechanism involves electrostatic interaction between the heavy metal ion and biosorbent surface. Characterisation techniques confirmed the interaction of microbes and oxidised carbon nanotubes with $\mathrm{Cr}(\mathrm{VI})$. A good sample volume of synthetic waste water sample was treated in lab scale column studies which could tolerate up to $4-5$ cycles of adsorption and desorption by regenerating the biosorbents using $1.0 \mathrm{~mol} \mathrm{~L}^{-1}$ sodium hydroxide. It was observed that CNTY has better adsorption capacity than CNTR owing to the larger accessibility of functional groups present in the microbial cell walls. On an optimistic note, biotechnology and nanoscience complement each other by opening diverse possibilities in detoxifying the pollutants from industrial waste water.

\section{Materials and Methods}

Chemicals and materials. All the chemicals used were analytical and guaranteed reagents. MWCNTs type 5 were procured from Sisco Research Laboratories, India with an outer diameter of 30-50 nm and length $10-30 \mu \mathrm{m}$. A $1000 \mathrm{mg} \mathrm{L}^{-1} \mathrm{Cr}(\mathrm{VI})$ stock solution was prepared from potassium dichromate $\left(\mathrm{K}_{2} \mathrm{Cr}_{2} \mathrm{O}_{7}, \mathrm{Merck}\right)$ and further dilutions were prepared accordingly in high purity Milli $\mathrm{Q}$ water. The solvents and salts used for $\mathrm{Cr}(\mathrm{VI})$ analysis using ion chromatography were supplied by Merck. The chemicals used to prepare YEPD medium (Yeast extract, peptone, dextrose) to culture yeast and YMA medium (Yeast extract, Mannitol, agar/ broth) for the growth of rhizobium were procured from Himedia. The chemicals used in coupling reaction were (3-Dimethylaminopropyl)-N'-ethylcarbodiimide hydrochloride (EDC), Hydroxybenzotriazole (HOBT)(Sisco Research Laboratories, India), triethylamine (Merck), dimethylformamide (SD Fine Chemicals Ltd, India).

Isolation and identification of microbial species. Rhizobium species. Rhizobium species was isolated from soil that was collected from nearby legume crop fields and followed a simple isolation procedure using standard pour plate technique on a YMA medium containing yeast extract, mannitol, $\mathrm{NaCl}, \mathrm{MgSO}{ }_{4}, \mathrm{~K}_{2} \mathrm{HPO}_{4}$, 
Congo red and agar. The inoculated plates were incubated at $37^{\circ} \mathrm{C}$ for 48 hours. Based on the morphological characteristics of the colonies, four isolates of the bacteria were selected (BI 1, BI 3, BI 4, BI 6). Further the isolates were subjected to morphological tests such as gram staining and motility tests, biochemical tests popularly known as IMVIC tests and molecular characterisations for the bacterial confirmation ${ }^{57}$.

Saccharomyces cerevisiae. The yeast granules purchased from local market were revived on YEPD medium and identified as S.cerevisiae through morphological and biochemical tests as reported by our group previously ${ }^{25}$.

Genomic DNA isolation and 16S rDNA PCR amplification. The bacterial genomic DNA was isolated according to a standard DNA isolation protocol ${ }^{58,59}$. The strains isolated were grown in $5 \mathrm{~mL}$ YMA medium at $37^{\circ} \mathrm{C}$ overnight and mid log phase of the culture obtained was harvested as a pellet by centrifugation. The pellet obtained was re-suspended in $500 \mu \mathrm{L}$ of TEG buffer (Tris-50mM EDTA-50mM Glucose -20\%) for the cell lysis. Further it was treated with lysozyme and RNAase at $37^{\circ} \mathrm{C}$ for $40 \mathrm{~min}$ followed by action of $10 \%$ SDS solution at $37^{\circ} \mathrm{C}$ for $60 \mathrm{~min}$. Isolation was accomplished by adding equivalent quantities of Phenol, Chloroform and Isoamyl alcohol followed by precipitating with $90 \%$ isopropanol (ice cold). The white DNA precipitate which was obtained was washed with $70 \%$ ethyl alcohol and suspended in $30 \mu \mathrm{L}$ TE (Tris-EDTA) buffer for further analysis.

The amplification of $16 \mathrm{~S}$ rDNA was performed using Polymerase chain reaction (PCR). The PCR reaction was setup using $25 \mu \mathrm{L}$ reaction mixture containing $200 \mu \mathrm{M} \mathrm{dNTP}, 1 \mu \mathrm{L}$ of Taq polymerase, $10 \times$ PCR buffer $(2.5 \mu \mathrm{L})$ with $\mathrm{MgCl}_{2}(1.5 \mathrm{mM}), 100 \mathrm{ng} / \mu \mathrm{l}$ genomic DNA, with $200 \mathrm{ng}$ of forward [27 F 5'-AGAGTTTGATCMTGGCTCG-3 ${ }^{\prime}$ ] and reverse primers $\left[1492 \mathrm{R} 5^{\prime} \text {-GGTTACCTTGTTACACTT- } 3^{\prime}\right]^{60}$. The PCR program was operated starting with initial denaturation at $94^{\circ} \mathrm{C}$ for $4 \mathrm{~min}$, followed by denaturation for $1 \mathrm{~min}$ at $94^{\circ} \mathrm{C}$ for $32 \mathrm{cycles}$, annealing at $58.5^{\circ} \mathrm{C}$ for $50 \mathrm{~min}$, extended for $2 \mathrm{~min}$ at $72^{\circ} \mathrm{C}$ followed by a final extension at $72^{\circ} \mathrm{C}$ for $10 \mathrm{~min}^{61}$ and the obtained product was resolved using electrophoresis. The purified amplicons were commercially sequenced. The sequences obtained were used to carry out a NCBI blast search analysis to confirm the identity of bacteria as Rhizobium $B V R$.

Preparation of the Rhizobium - MWCNTs and Yeast - MWCNTs biosorbent. The isolated Rhizobium species was grown in yeast- mannitol broth medium and spun down to make a pellet. The yeast grown on YEPD medium was used ${ }^{25}$. Pristine MWCNTs were functionalised by covalent modification as reported previously $^{31,62}$. A $200 \mathrm{~mL}$ of $0.5 \mathrm{~mol} \mathrm{~L}^{-1} \mathrm{H}_{2} \mathrm{SO}_{4}$, was mixed with $0.25 \mathrm{~g}$ of $\mathrm{KMnO}_{4}$ as an initial step for oxidation. In another beaker, $0.1 \mathrm{~g}$ of MWCNTs, $200 \mathrm{~mL}$ of $0.5 \mathrm{~mol} \mathrm{~L}^{-1} \mathrm{H}_{2} \mathrm{SO}_{4}$ was added and subjected to ultra-sonication for $30 \mathrm{~min}$ to ensure proper dispersion. After sonication the solution containing MWCNTs was heated up to $150^{\circ} \mathrm{C}$ prior to the addition of $\mathrm{KMnO}_{4}$ solution dropwise. The mixed solution was refluxed for 5 hours at $150^{\circ} \mathrm{C}$ and cooled down to room temperature proceeded by the addition of $10 \mathrm{~mL}$ of concentrated $\mathrm{HCl}$ to dissolve $\mathrm{MnO}_{2}$. The oxidised MWCNTs were washed till the $\mathrm{pH}$ reached between $6.0-7.0$ and then dried at $100^{\circ} \mathrm{C}$.

The dried MWCNTs were further used in the preparation of biosorbent along with microbes (free amine sources) by involving in EDC-HOBT coupling. To $0.1 \mathrm{~g}$ of oxidised MWCNTs, $0.1 \mathrm{~g}$ each of EDC, HOBT were added. The solvent used was DMF (dimethyl formamide) and $3 \mathrm{~mL}$ of triethylamine was added to the above mixture and stirred for 20 minutes. $3.0 \mathrm{~g}$ of yeast was added to the solution and the mixture was stirred overnight for the coupling reaction to take place ${ }^{63}$. Similar procedure was repeated for the coupling reaction with Rhizobium $B V R$. The coupling mixture was filtered, washed with water and dried at $80^{\circ} \mathrm{C}$ for 4 hours before proceeding for metal adsorption studies.

Synthesis of probes for $\mathrm{Cr}(\mathrm{VI})$ and $\mathrm{Cr}(\mathrm{III})$. $\quad \mathrm{Cr}(\mathrm{VI})$ and $\mathrm{Cr}(\mathrm{III})$ have specific binding probes to differentiate them. Rhodamine based sensors are selected due to its spiro lactam structure and spiro ring opening of sensing a molecule. Rhodamine B hydrazide $(\mathrm{RBH})^{45}$ and Rhodamine based chemo sensor $(\mathrm{RF})^{46}$ were synthesized as described in literature which are specific for $\mathrm{Cr}(\mathrm{VI})$ and $\mathrm{Cr}(\mathrm{III})$ respectively and the samples were prepared for capturing the laser confocal images.

Characterisation techniques. The developed biosorbent was characterized using various analytical techniques before and after $\mathrm{Cr}(\mathrm{VI})$ adsorption. FTIR analysis was performed for the Pristine CNT, microbe-carbon adsorbent (before as well as after adsorption) using JASCO- 4200 model spectrometer $\left(400-4000 \mathrm{~cm}^{-1}\right)$ where $1.0 \mathrm{mg}$ of the samples were mixed with $100 \mathrm{mg}$ of $\mathrm{KBr}$ and the individual spectra were recorded. Thermogravimetric analysis (TGA) of the biosorbent was recorded using a Shimadzu DTG-60 thermal analyser. A known weight of the biosorbent was taken and subjected to a temperature range of $30-800^{\circ} \mathrm{C}$ under air atmosphere to analyze the thermal stability. For the elemental analysis energy dispersive X-ray spectra (EDAX) was recorded using Bruker - X Flash 6/30 and to study the surface morphology of the biosorbents, field emission scanning electron microscopic (FESEM) images were captured using Carl Zeiss Supra 55 and High resolution transmission electron microscopic (HRTEM) images taken by Tecnai 20 (FEI) $200 \mathrm{kV}$ gives an insight into the microstructure and the defects at atomic resolution. The elemental speciation was ascertained by X-ray photo electron spectroscopy using PHI 5000 Versa Prob II, FEI Inc, and the source used is an aluminium monochromator at $25.4 \mathrm{~W}$ and $187.85 \mathrm{eV}$. The BET surface area, $\mathrm{BJH}$ pore volume and average pore diameter of the biosorbent were measured using a BELSORP II mini (Microtrac BEL Corp) at an outgassing temperature of $150^{\circ} \mathrm{C}$ for 2 hour duration. LeicaDMi8 laser scanning microscopy (S/N 418513) was used to capture confocal images. The quantitative $\mathrm{Cr}(\mathrm{VI})$ adsorption was performed using 883 Basic IC plus Ion chromatography ${ }^{64}$ with a 887 professional UV/Vis detector. The $16 \mathrm{~S}$ rDNA sequencing was carried out using the Biosystems ABI 3730 xls Genetic analyser at Bioserve Pvt. Ltd., Hyderabad, India. Matrix assisted laser desorption ionisation time of flight (MALDI-TOF) 
was performed using VITEK MS (Biomerieux) spectrometer, with the knowledge Base v2 database (closed) at Zeal Biologicals, Hyderabad, India for the confirmation of the isolated bacteria.

Batch adsorption studies. The batch adsorption studies were performed by optimizing various parameters such as $\mathrm{pH}$, adsorbent dosage, kinetics, thermodynamics. A $0.1 \mathrm{~g}$ of the biosorbent was used to treat $20 \mathrm{~mL}$ of $5 \mathrm{mg} \mathrm{L}^{-1} \mathrm{Cr}(\mathrm{VI})$ solution at $\mathrm{pH}$ 2.0. The equilibration was performed for $180 \mathrm{~min}$ using an orbital incubator shaker (Biotechnics, India) operating at $120 \mathrm{rpm}$ maintained at $30^{\circ} \mathrm{C}$. After separation of the biosorbent through filtration, the concentration of $\mathrm{Cr}(\mathrm{VI})$ was estimated using ion chromatography coupled with a UV detector and the amount of $\mathrm{Cr}(\mathrm{VI})$ adsorbed onto the developed biosorbents was calculated as

$$
\mathrm{q}_{\mathrm{e}}=\frac{\left(\mathrm{C}_{\mathrm{o}}-\mathrm{C}_{\mathrm{e}}\right) \mathrm{V}}{\mathrm{W}}
$$

$\mathrm{q}_{\mathrm{e}}=$ amount of $\mathrm{Cr}(\mathrm{VI})$ adsorbed $\left(\mathrm{mg} \mathrm{g}^{-1}\right)$ onto biosorbent. $\mathrm{C}_{\mathrm{o}}=$ initial $\mathrm{Cr}(\mathrm{VI})$ concentration. $\mathrm{Ce}=\mathrm{Cr}(\mathrm{VI})$ concentration remaining in solution phase. $\mathrm{V}=$ Volume of $\mathrm{Cr}(\mathrm{VI})$ solution used for biosorption $(\mathrm{L}) . \mathrm{W}=$ weight of the biosorbent used for $\mathrm{Cr}(\mathrm{VI})$ treatment $(\mathrm{g})$.

\section{References}

1. He, X. et al. Analysis of four toxic metals in a single rice seed by matrix solid phase dispersion -inductively coupled plasma mass spectrometry. Sci. Rep. 6, 38472 (2016).

2. Kalidhasan, S., Kumar, A. S. K., Rajesh, V. \& Rajesh, N. The journey traversed in the remediation of hexavalent chromium and the road ahead toward greener alternatives-A perspective. Coord. Chem. Rev. 317, 157-166 (2016).

3. Puneet, C., Krishna, V., Venu Gopal, A. \& Joshi, S. V. CrAlSiN nanocomposite thin films for high-speed machining applications. Mater. Manuf. Process. 2017, 1303157, https://doi.org/10.1080/10426914 (2017).

4. Alimba, C. G., Dhillon, V., Bakare, A. A. \& Fenech, M. Genotoxicity and cytotoxicity of chromium, copper, manganese and lead, and their mixture in WIL2-NS human B lymphoblastoid cells is enhanced by folate depletion. Mutat. Res. Genet. Toxicol. Environ. Mutagen. 798-799, 35-47 (2016).

5. Gutierrez-Corona, J. F., Romo-Rodríguez, P., Santos-Escobar, F., Espino-Saldana, A. E. \& Hernández-Escoto, H. Microbial interactions with chromium: basic biological processes and applications in environmental biotechnology. World J.Microbiol. Biotechnol. 32, 191 (2016).

6. Analytical Feasibility Support Document for the Second Six-Year Review of Existing National Primary Drinking Water Regulations. EPA 815-B-09-003 https://www.epa.gov/sites/production/files/2014-12/documents/815b09003.pdf (2009).

7. Panda, H., Tiadi, N., Mohanty, M. \& Mohanty, C. R. Studies on adsorption behavior of an industrial waste for removal of chromium from aqueous solution. South African Journal of Chemical Engineering. 23, 132-138 (2017).

8. Ahmad, R. \& Hasan, I. Efficient Remediation of an aquatic environment contaminated by $\mathrm{Cr}$ (VI) and 2, 4-dinitrophenol by XG-gpolyaniline@ZnO nanocomposite. J. Chem. Eng. Data. 62, 1594-1607 (2017).

9. Zhao, R. et al. Branched polyethylenimine grafted electrospun polyacrylonitrile fibre membrane: A novel and effective adsorbent for $\mathrm{Cr}$ (VI) remediation in waste water. J. Mater. Chem. A 5, 1133-1144 (2017).

10. Wen, T. et al. A core-shell structure of polyaniline coated protonic titanate nanobelt composites for both $\mathrm{Cr}(\mathrm{VI})$ and humic acid removal. Polym. Chem. 7, 785-794 (2016).

11. Jiang, X., Luo, H., Yin, Y. \& Zhou, W. Facile synthesis of $\mathrm{MoS}_{2} /$ reduced graphene oxide composites for efficient removal of $\mathrm{Cr}(\mathrm{VI})$ from aqueous solutions. RSC Adv. 7, 24149-24156 (2017).

12. Zhuang, Y. T., Zhu, T. T., Ruan, M., Yu, Y. L. \& Wang, J. H. A 2D porous $\mathrm{Fe}_{2} \mathrm{O}_{3} /$ graphitic- $\mathrm{C}_{3} \mathrm{~N}_{4} /$ graphene ternary nanocomposite with multifunctions of catalytic hydrogenation, chromium (VI) adsorption and detoxification. J. Mater. Chem. A. 5, 3447-3455 (2017).

13. Rafatullah, M., Sulaiman, O., Hashima, R. \& Ahmad, A. Adsorption of methylene blue on low-cost adsorbents: A review. J. Hazard. Mater. 177, 70-80 (2010).

14. Yu, P. et al. Self-Assembled Sponge-like Chitosan/Reduced Graphene Oxide/Montmorillonite Composite Hydrogels without CrossLinking of Chitosan for Effective Cr(VI) Sorption. ACS Sustainable Chem. Eng. 5, 1557-1566 (2017).

15. Luo, T. et al. Polyethylenimine-Functionalized Corn Bract, an Agricultural Waste Material, for Efficient Removal and Recovery of $\mathrm{Cr}$ (VI) from Aqueous Solution. J. Agric. Food Chem. 65, 7153-7158 (2017).

16. Long, D. et al. $\mathrm{Cr}(\mathrm{VI})$ resistance and removal by indigenous bacteria isolated from chromium-contaminated soil. J Microbiol Biotechnol. 23, 1123-32 (2013).

17. Fomina, M. \& Gadd, G. M. Biosorption: current perspectives on concept, definition and application. Bioresour. Technol. 160, 3-14 (2014).

18. Dodson, J. R. et al. Bio-derived materials as a green route for precious \& critical metal recovery and re-use. Green Chem. 17, 1951-1965 (2015).

19. Sathvika, T., Manasi, Rajesh, V. \& Rajesh, N. Prospective application of Aspergillus species immobilized in sodium montmorillonite to remove toxic hexavalent chromium from wastewater. RSC Adv. 5, 107031-107044 (2015).

20. Sathvika, T., Manasi, Rajesh, V. \& Rajesh, N. Adsorption of chromium supported with various column modelling studies through the synergistic influence of Aspergillus and cellulose. J. Environ. Chem. Eng. 4, 3193-3204 (2016).

21. Dogan, N. M. et al. Chromium(VI) bioremoval by Pseudomonas bacteria: role of microbial exudates for natural attenuation and biotreatment of $\mathrm{Cr}(\mathrm{VI})$ contamination. Environ. Sci. Technol. 45, 2278-2285 (2011).

22. Qian, J. et al. An exploratory study on the pathways of $\mathrm{Cr}$ (VI) reduction in sulfate-reducing up-flow anaerobic sludge bed (UASB) reactor. Sci. Rep. 6, 23694 (2016).

23. Choudhury, P. R. et al. Removal of Cr (VI) by synthesized titania embedded dead yeast nanocomposite: Optimization and modeling by response surface methodology. J. Environ. Chem. Eng. 5, 214-221 (2017).

24. Colica, G., Mecarozzi, P. C. \& De Philippis, R. Biosorption and recovery of chromium from industrial wastewaters by using Saccharomyces cerevisiae in a flow-through system. Ind. Eng. Chem. Res. 51, $4452-4457$ (2012).

25. Sathvika, T., Manasi, Rajesh, V. \& Rajesh, N. Microwave assisted immobilization of yeast in cellulose biopolymer as a green adsorbent for the sequestration of chromium. Chem.Eng.J. 279, 38-46 (2015).

26. Sivakumaran, S., Lockhart, P. J. \& Jarvis, B. D. Identification of soil bacteria expressing a symbiotic plasmid from Rhizobium leguminosarum bv. Trofolii. Can. J.Microbiol. 43, 164-77 (1997).

27. Ehteshamul-haque, S. \& Ghaffar, A. Use of Rhizobia in the control of root rot diseases of sunflower, okra, soybean and mung bean. J. Phytopathology. 138, 157-163 (1993).

28. Rebah, F. B., Prévost, D., Yezza, A. \& Tyagi, R. D. Agro-industrial waste materials and wastewater sludge for rhizobial inoculant production: a review. Bioresour Technol. 98, 3535-46 (2007).

29. Raaman, N., Mahendran, B., Jaganathan, C., Sukumar, S. \& Chandrasekaran, V. Removal of chromium using Rhizobium leguminosarum. World. J. Microbiol. Biotechnol. 28, 627-636 (2012). 
30. Karthik, C., Oves, M., Sathya, K., Sri Ramkumar, V. \& Arulselvi, P. I. Isolation and characterization of multi-potential Rhizobium strain ND2 and its plant growth promoting activities under Cr(VI) stress. Arch. Agron. Soil. Sci. 63, 1058-1069 (2017).

31. Parlayici, S., Eskizeybek, V., Avc1, A. \& Pehlivan, E. Removal of chromium (VI) using activated carbon-supported functionalized carbon nanotubes. J Nanostruct Chem. 5, 255-263 (2015).

32. Lua, W. et al. One-pot synthesis of magnetic iron oxide nanoparticle-multiwalled carbon nanotube composites for enhanced removal of $\mathrm{Cr}(\mathrm{VI})$ from aqueous solution. J Colloid Interface Sci. 505, 1134-1146 (2017).

33. Masheane, M. L. et al. Synthesis of Fe-Ag/f-MWCNT/PES nanostructured-hybrid membranes for removal of $\mathrm{Cr}(\mathrm{VI})$ from water. Sep. Purif. Technol. 184, 79-87 (2017).

34. Salam, M. A. Preparation and characterization of chitin/magnetite/multiwalledcarbon nanotubes magnetic nanocomposite for toxic hexavalent chromium removal from solution. J. Mol. Liq. 233, 197-202 (2017).

35. Yan, F. F. et al. Carbon nanotubes promote Cr(VI) reduction by alginate-immobilized Shewanella oneidensis MR-1. Biochem. Eng. J. 77, 183-189 (2013).

36. Tuzen, M., Saygi, K. O., Usta, B. \& Soylak, M. Pseudomonas aeruginosa immobilized multiwalled carbon nanotubes as biosorbent for heavy metal ions. Bioresour Technol. 99, 1563-1570 (2008).

37. Kumar, A. S. K., Jiang, S. J. \& Tseng, W. L. Effective adsorption of chromium(VI)/Cr(III) from aqueous solution using ionic liquid functionalized mulitwalled carbon nanotube as a super sorbent. J. Mater. Chem. A. 3, 7044-7057 (2015).

38. Naumann, D. Infra-red Spectroscopy in Microbiology, Encyclopedia of Analytical Chemistry (ed. Meyers, R. A.) 102-131 (John Wiley and Sons Ltd, 2000).

39. Zhao, J. \& Wang, J. Understanding the amide-II vibrations in $\beta$-peptides. J. Phys. Chem. B. 119, 14831-14839 (2015).

40. Kumar, A. S. K., Jiang, S. J. \& Warcho, J. K. Synthesis and Characterization of Two-Dimensional Transition Metal Dichalcogenide Magnetic MoS2@Fe3O4 Nanoparticles for Adsorption of Cr(VI)/Cr(III).ACS Omega. 2, 6187-6200 (2017).

41. Zheng, W. et al. Efficient batch and column removal of $\mathrm{Cr}(\mathrm{VI})$ by carbon beads with developed nano-network. RSC Adv. $\mathbf{6}$, 104897-104910 (2016).

42. Reigh, G. \& Connell, M. O. Siderophore-mediated iron transport correlates with the presence of specific iron-regulated proteins in the outer membrane of Rhizobium meliloti. J Bacteriol. 175, 94-102 (1993).

43. Bae, Y. S., Yazaydın, A. O. \& Snurr, R. Q. Evaluation of the BET Method for Determining Surface Areas of MOFs and Zeolites that Contain Ultra-Micropores. Langmuir 26, 5475-5483 (2010).

44. Yadav, S. K., Mahapatra, S. S., Yadav, M. K. \& Dutta, P. K. Mechanically robust bio composite films of chitosan grafted carbon nanotubes via [2+1] cycloaddition of nitrene. RSC Adv. 3, 23631-23637 (2013).

45. Xiang, Y., Mei, L., Li, N. \& Tong, A. Sensitive and selective spectrofluorometric determination of chromium(VI) in water by fluorescence enhancement. Anal. Chim. Acta. 581, 132-136 (2007).

46. Zhou, Y. et al. A rhodamine-based fluorescent enhancement chemosensor for the detection of $\mathrm{Cr}^{3+}$ in aqueous media. Dyes. Pigm. 97, 148-154 (2013).

47. Anslyn. E. V. \& Dougherty, D. A. Modern Physical Organic Chemistry. Ch. 10, 603-604 (University Science Books, 2006).

48. Lagergren, S. About the theory of so-called adsorption of soluble substances. K. Sven. Vetenskapsakad. Handl. 24, 1-39 (1898).

49. Ho, Y. S. \& Mckay, G. The kinetics of sorption of divalent metal ions onto sphagnum moss peat. Water Res. 34, 735-742 (2000).

50. Fierro, V., Torne-Fernandez, T., Montane, D. \& Celzard, A. Adsorption of phenol onto activated carbons having different textural and surface properties. Microporous Mesoporous Mater. 111, 276-284 (2008).

51. Sun, L. et al. Removal of $\mathrm{I}^{-}$from aqueous solutions using a biomass carbonaceous aerogel modified with KH-560. ACS Sustainable Chem. Eng. 5, 7700-7708 (2017).

52. Hasan, S. H., Ranjan, D. \& Talat, M. Agro-industrial waste wheat bran for the biosorptive remediation of selenium through continuous up-flow fixed-bed column. J. Hazard. Mater. 181, 1134-1142 (2010).

53. Kumar, A. S. K., Kalidhasan, S., Rajesh, V. \& Rajesh, N. Application of cellulose-clay composite biosorbent toward the effective adsorption and removal of chromium from industrial wastewater. Ind. Eng. Chem. Res. 51, 58-69 (2012).

54. Bergey's Manual of Systematic Bacteriology. Vol 2 The Proteobacteria. Part C, (Garrity, G. et al.) 325-326 (Springer, 2005)

55. Uscanga, B. A. \& Francois, J. M. A study of the yeast cell wall composition and structure in response to growth conditions and mode of cultivation. Lett Appl Microbiol. 37, 268-284 (2003).

56. Salton, J. The relationship between the nature of the cell wall and the gram stain. J. Gen. Microbiol. 30, 223-235 (1963).

57. Loiret, F. G. et al. A putative new endophytic nitrogen-fixing bacterium Pantoea sp. from sugarcane. J. Appl. Microbiol. 97, 504-511 (2004).

58. Chen, W. P. \& Kuo, T. T. A simple and rapid method for the preparation of gram negative bacterial genomic DNA. Nucleic Acids Res. 21, 2260 (1993)

59. Sambrook, J. \& Russel, D. W. Molecular cloning- A laboratory manual. Vol. 1 Ch. 1, 19-20 (Cold Spring Harbor Laboratory Press, 2012).

60. Tamas, E. et al. Microbial products as natural alternative to fertilizers: isolation and characterization of nitrogen fixing bacteria. U.P.B. Sci. Bull. 72, 137-144 (2010).

61. Rincon, A. et al. Diversity of Rhizobial bacteria isolated from nodules of the gypsophyte Ononistridentata L. Growing in Spanish Soils. Microb. Ecol. 56, 223-233 (2008).

62. Rastian, Z. et al. Facile surface functionalization of multiwalled carbon nanotubes by soft dielectric barrier discharge plasma: Generate compatible interface for lipase immobilization. Biochem. Eng. J. 90, 16-26 (2014).

63. Sheehan, J. C., Cruickshank, P. A. \& Boshart, G. L. Convenient synthesis of water-soluble carbodiimides. J. Org. Chem. 26, 2525 (1961).

64. Arar, E. J. \& Pfaff, J. D. Determination of dissolved hexavalent chromium in industrial wastewater effluents by ion chromatography and post-column derivatization with diphenyl carbazide. J. Chromatogr. A. 546, 335-340 (1991).

\section{Acknowledgements}

The authors acknowledge the Department of Science and Technology, India (DST-SERB) for funding (SR/S1/ IC-06/2012) the project. We thank Central Analytical Laboratory, BITS Pilani Hyderabad Campus, Sprint testing solutions, Mumbai, India and the surface characterisation lab, IIT Kanpur, India and for their assistance in biosorbent characterisation.

\section{Author Contributions}

The experiments were designed and coordinated by V.R. and N.R. and the isolation of Rhizobium BVR was carried out by T.S. and M.M. and the adsorption experiments and analysis were carried out by T.S. A.S., K.S., M.P. All authors have approved the manuscript.

Additional Information

Supplementary information accompanies this paper at https://doi.org/10.1038/s41598-018-28067-9. 
Competing Interests: The authors declare no competing interests.

Publisher's note: Springer Nature remains neutral with regard to jurisdictional claims in published maps and institutional affiliations.

(c) (i) Open Access This article is licensed under a Creative Commons Attribution 4.0 International License, which permits use, sharing, adaptation, distribution and reproduction in any medium or format, as long as you give appropriate credit to the original author(s) and the source, provide a link to the Creative Commons license, and indicate if changes were made. The images or other third party material in this article are included in the article's Creative Commons license, unless indicated otherwise in a credit line to the material. If material is not included in the article's Creative Commons license and your intended use is not permitted by statutory regulation or exceeds the permitted use, you will need to obtain permission directly from the copyright holder. To view a copy of this license, visit http://creativecommons.org/licenses/by/4.0/.

(c) The Author(s) 2018 